\title{
Possible metazoan egg fossils from the Darriwilian (Middle Ordovician) of Baltoscandia
}

\author{
Olle Hints ${ }^{\mathrm{a}}$, Jaak Nõlvak ${ }^{\mathrm{a}}$ and Yan Liang ${ }^{\mathrm{b}}$ \\ a Department of Geology, Tallinn University of Technology, Ehitajate tee 5, 19086 Tallinn, Estonia; olle.hints@taltech.ee \\ ${ }^{\mathrm{b}}$ State Key Laboratory of Palaeobiology and Stratigraphy, Nanjing Institute of Geology and Palaeontology, Chinese Academy of \\ Sciences, Nanjing 210008, China
}

Received 11 October 2021, accepted 25 October 2021, available online 16 November 2021

\begin{abstract}
The Baltoscandian lower Palaeozoic succession is well known for the abundance, diversity and excellent preservation of various groups of microfossils, such as acritarchs, chitinozoans, scolecodonts and conodonts. This paper describes a new enigmatic Middle Ordovician organic-walled microfossil Vikisphaera kundana gen. et sp. nov., characterized by a dark brown to black hollow spherical shell, 90-200 $\mu \mathrm{m}$ in diameter, with an equatorial groove and lack of openings. The specimens of Vikisphaera have been collected from several localities across Baltoscandia including Estonia, Sweden, Latvia and northwestern Russia, and their stratigraphic range is restricted to the Kunda Regional Stage, lower Darriwilian. The wide geographical distribution and short temporal range of Vikisphaera imply its biostratigraphic utility. The shape and characteristics of the shell wall of Vikisphaera are different from those of prasinophytes and other organic-walled microfossils common in lower Palaeozoic rocks. The new microfossil resembles egg shells of some invertebrates, such as arthropods, suggesting that it could represent egg capsules of a group of marine metazoans, possibly soft-bodied creatures with low fossilization potential. However, before the metazoan origin of Vikisphaera is confirmed, it can be considered as an acritarch - an organic-walled microfossil of unknown affinity.
\end{abstract}

Key words: microfossils, fossil eggs, Middle Ordovician, Darriwilian, Kunda Regional Stage, Baltoscandia.

\section{INTRODUCTION}

Various types of organic-walled microfossils (chitinozoans, foraminiferans, acritarchs, prasinophytes, scolecodonts, melanosclerites, hydroids and others) are abundant and diverse in lower Palaeozoic carbonate rocks of the Baltic region. They have been systematically collected and described since the pioneering works of Alfred Eisenack in the 1930s (Eisenack 1931, 1932, 1934, 1937). In several cases the biological affinity of a particular microfossil group has remained unknown or debatable. For instance, a number of hypotheses have been put forward to explain the origin of chitinozoans (see overview in Miller 1996), a common interpretation being that they are egg shells of cryptic marine metazoans (Paris \& Nõlvak 1999), or perhaps cases of microscopic protozoans (Liang et al. 2019, 2020). The uncertain biological origin of chitinozoans has nevertheless not limited their application in biostratigraphy (e.g. Nõlvak \& Grahn 1993; Verniers et al. 1995; Webby et al. 2004a) or prevented analysing the diversification of 'chitinozoan animals' (Achab \& Paris 2007; Grahn \& Paris 2011; Hints et al. 2018; Liang et al. 2018).
Several microfossil groups appeared and/or diversified rapidly during the Early and Middle Ordovician. This pulse of radiation is part of the Great Ordovician Biodiversification Event - the GOBE (Webby et al. 2004b; Harper 2006; Servais et al. 2010; Rasmussen et al. 2016, 2019; Harper et al. 2020). Over the years, hundreds of micropalaeontological samples from tens of sections in the Baltic region have been collected and studied from this time span in order to trace the distribution and reconstruct the regional diversification history of chitinozoans and scolecodonts (Hints 2000; Paris et al. 2004; Hints \& Eriksson 2007; Hints et al. 2018). In addition to these two groups, many other microfossils have been picked from the samples and stored for future study.

Recently, the examination of Darriwilian samples from the Viki reference drill core from Saaremaa Island, western Estonia (Hints et al. 2014), revealed an unknown type of spherical organic-walled microfossils that were cooccurring with chitinozoans, acritarchs, prasinophyte algae and scolecodonts. These dark brown to black hollow shells, $c a 140 \mu \mathrm{m}$ in diameter, with variable wall thickness and a characteristic equatorial groove were mostly 
preserved 3-dimensionally and had no openings in the shell. The broken specimens were either split into two halves or had an irregularly broken wall. The discovery of these unusual forms motivated re-inspection of the previously studied Darriwilian samples from other sections. Surprisingly, the same spherical fossils were present, albeit less abundantly, in several localities across the Baltoscandian Palaeobasin, always within a restricted stratigraphic interval in the Kunda Regional Stage, lower Darriwilian, Middle Ordovician. They had been initially overlooked due to their similar shape, colour and size range with Tasmanites-type prasinophytes - the diagnostic groove on the new fossil becomes visible only when using sufficiently high magnifications.

The aim of this study is to describe the new enigmatic fossil group and its only representative, Vikisphaera kundana gen. et sp. nov., document its stratigraphic and geographic distribution and discuss its possible biological affinities. We also encourage other researchers of acid-resistant microfossils to seek the occurrence of similar palynomorphs in other regions and stratigraphic levels.

\section{GEOLOGICAL BACKGROUND AND STRATIGRAPHY}

The Baltoscandian Basin covered a large area of the Baltica palaeocontinent during the Kunda Age, early to middle Darriwilian (Fig. 1). Baltica was then located between 60 and 40 southern latitudes (Cocks \& Torsvik 2005, 2020; Torsvik \& Cocks 2013) and the Baltoscandian Basin was characterized by the deposition of cool-water to temperate carbonates and siliciclastic muds. Three major facies zones have been distinguished within the basin during this time (Männil 1966). A relatively shallow-water setting with dominance of grey carbonate sediments was typical of northern and central Estonia and northwestern Russia. Deeper shelf environments, where largely red-coloured carbonates accumulated, were present in Latvia, Lithuania and Sweden (Fig. 1), whereas the deepest basin with dark organic-rich muds covered southern Sweden and Denmark (Männil 1966). The localities studied in this work were part of the former two regions, spanning from Sweden to Estonia, Latvia and northwestern Russia (Fig. 1). In most part of Baltoscandia, the Darriwilian succession is only few tens of metres thick, suggesting average accumulation rates below $c a$ $5 \mathrm{~mm} \mathrm{ka}{ }^{-1}$ over large areas within a sediment-starved basin (Bergström et al. 2011; Hints et al. 2012; Lindskog et al. 2017). Ordovician rocks in eastern Baltoscandia are generally well preserved; however, late diagenetic recrystallization of carbonate minerals has been identified, reflecting influences from the Caledonian front during mid Palaeozoic times (Hagen-Peter et al. 2021).

The lower Darriwilian stratigraphic framework in Baltoscandia is based on trilobite, conodont, chitinozoan and graptolite biostratigraphy, which, in combination with lithostratigraphy, forms the foundation of traditional regional stages and substages (for overview see Nõlvak et al. 2006; Pärnaste et al. 2013). Graptolites are found abundantly only in the deepest part of the basin (Bergström et al. 2018), and thus conodonts and chitinozoans provide the most convenient correlation tools in this interval. The Kunda Regional Stage of the Baltoscandian chronostratigraphic subdivision, which hosts all finds of Vikisphaera,

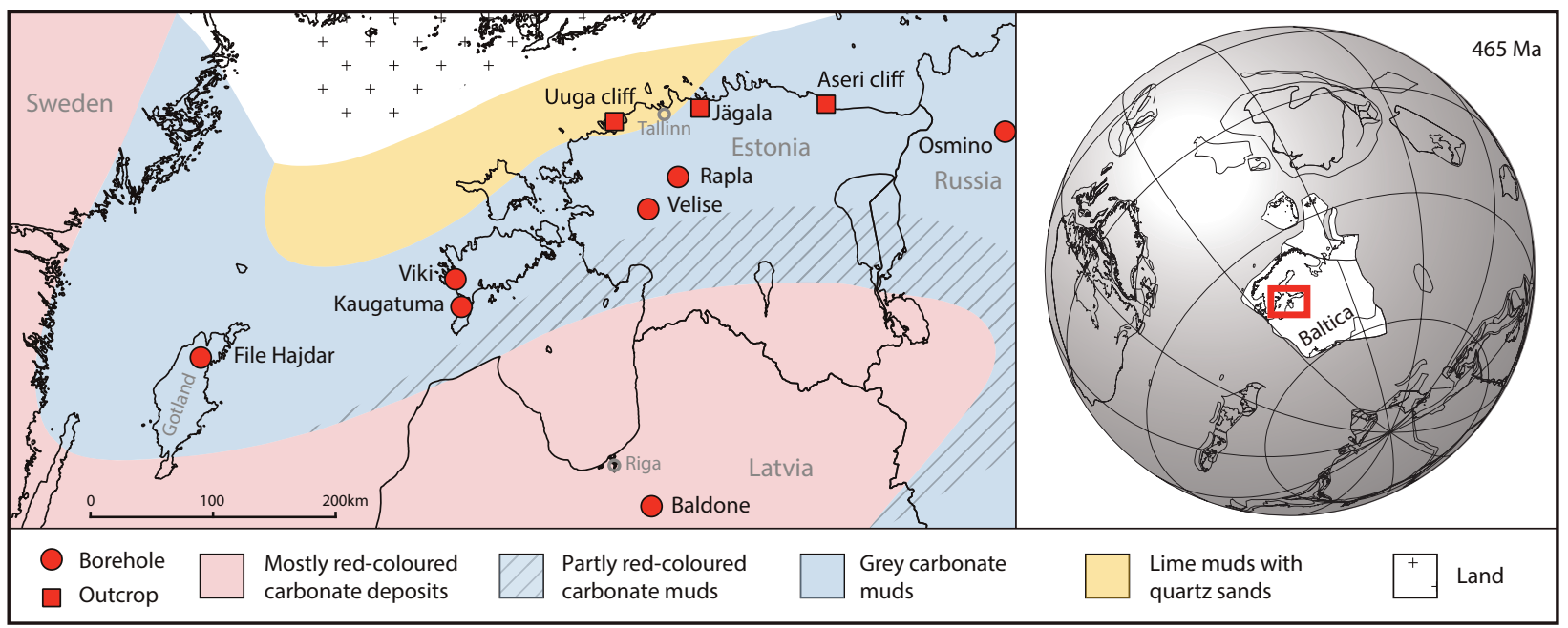

Fig. 1. Baltoscandian Palaeobasin during Kunda time, showing the spatial distribution of Vikisphaera kundana gen. et sp. nov. Palaeobasin configuration after Männil (1966); global palaeogeographic map drawn using BugPlates software (courtesy to Trond Torsvik, http://www.earthdynamics.org). 


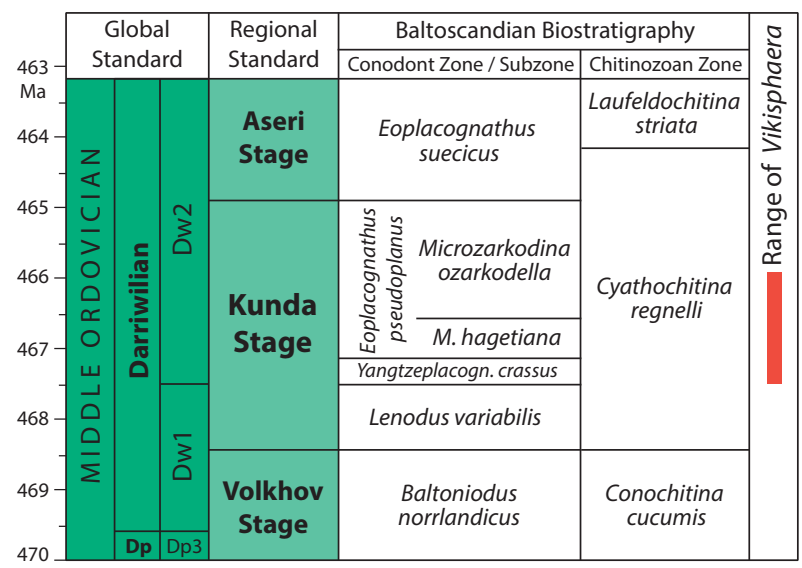

Fig. 2. Stratigraphic background and temporal distribution of Vikisphaera kundana gen. et sp. nov. Regular time scale after Lindskog et al. (2017). Dp, Dapingian.

corresponds to the Lenodus variabilis, Yangtzeplacognathus crassus and Eoplacognathus pseudoplanus conodont zones in the Upper Dw1 and lower Dw2 stage slices of Bergström et al. (2009). Recent age dates from southern Sweden have allowed precise calibration of the regional stratigraphic units to the numerical time scale (Lindskog et al. 2017), suggesting that the Kunda Age spans from ca 465 to $468.5 \mathrm{Ma}$ (Fig. 2).

The rocks of the Kunda Regional Stage are rich in shelly faunas, such as cephalopods, trilobites, gastropods, brachiopods, bryozoans, ostracods and others (Meidla 1997). The acid-resistant microfossil assemblage is usually dominated by acritarchs, conodonts, chitinozoans and scolecodonts. It is noteworthy that this interval corresponds to a significant pulse of biodiversification, perhaps the critical part of the GOBE on Baltica, which is especially well illustrated by the data on brachiopods (Rasmussen et al. 2016). Acid-resistant microfossils such as chitinozoans and scolecodonts also show rapid diversification during this interval in Baltoscandia (Hints 2000; Nõlvak et al. 2019).

A special feature of the Kunda Regional Stage in Baltoscandia is the occurrence of fossil meteorites originating from an asteroid break-up at ca $468 \mathrm{Ma}$ (Schmitz et al. 2007). The latter authors linked this event to the onset of the GOBE, although more recent data have cast doubt on this hypothesis (Lindskog et al. 2017). The occurrence interval of Vikisphaera largely predates the Middle Darriwilian carbon isotope excursion (Ainsaar et al. 2010).

\section{MATERIAL AND METHODS}

The material described in this paper has been collected in the course of chitinozoan and conodont studies using conventional micropalaeontological techniques (Nõlvak et al. 2019). Organic-walled microfossils were extracted from limestone samples, mostly $50-800 \mathrm{~g}$ each, by dissolving the matrix in acetic or hydrochloric acid. The insoluble residues were washed through a $40-63-\mu \mathrm{m}$ sieve and hand-picked for different microfossil groups (chitinozoans, scolecodonts, conodonts, graptolites as well as problematic fossils) under a stereomicroscope.

Altogether, more than a thousand specimens of enigmatic Vikisphaera were recovered from ten sections. The fossils are stored in small plastic containers within glycerin or clued to SEM stubs for imaging. Light microscopy images were obtained using a Nikon AZ100 microscope equipped with a Nikon digital camera. For extended depth of field, multiple images were stacked.

The numbered specimens, preparations and samples are deposited at the Department of Geology, Tallinn University of Technology (institutional abbreviation: GIT).

\section{SYSTEMATIC PALAEONTOLOGY}

\author{
Phylum, Class, Order and Family uncertain \\ Genus Vikisphaera new genus
}

Type species. Vikisphaera kundana gen. et sp. nov.; by monotypy.

Etymology. After the Viki reference drill core, Saaremaa Island, western Estonia, from where the genus has been most abundantly recovered, and referring to the spherical shape.

Diagnosis. Organic-walled brown to black hollow spherical microfossils, 90-200 $\mu \mathrm{m}$ in diameter; shell without any openings, but with a distinct equatorial groove and two tiny ridges along the groove; shell often broken into two halves along the groove; outer surface smooth or slightly undulating, inner surface smooth; shell wall highly variable, 3-30 $\mu \mathrm{m}$ thick, porous or sponge-like.

Occurrence. Lower Darriwilian (Middle Ordovician) of Baltoscandia.

\section{Vikisphaera kundana sp. nov.} Figures 3, 4

Holotype. GIT 742-1, Fig. 4A.

Type locality. Viki drill core, depth 360.75-361.25 m, Saaremaa Island, western Estonia.

Type horizon. Loobu Formation, Kunda Regional Stage, lower Darriwilian.

Etymology. After the Kunda Regional Stage, the only stratigraphic unit, where the species is known to occur. 


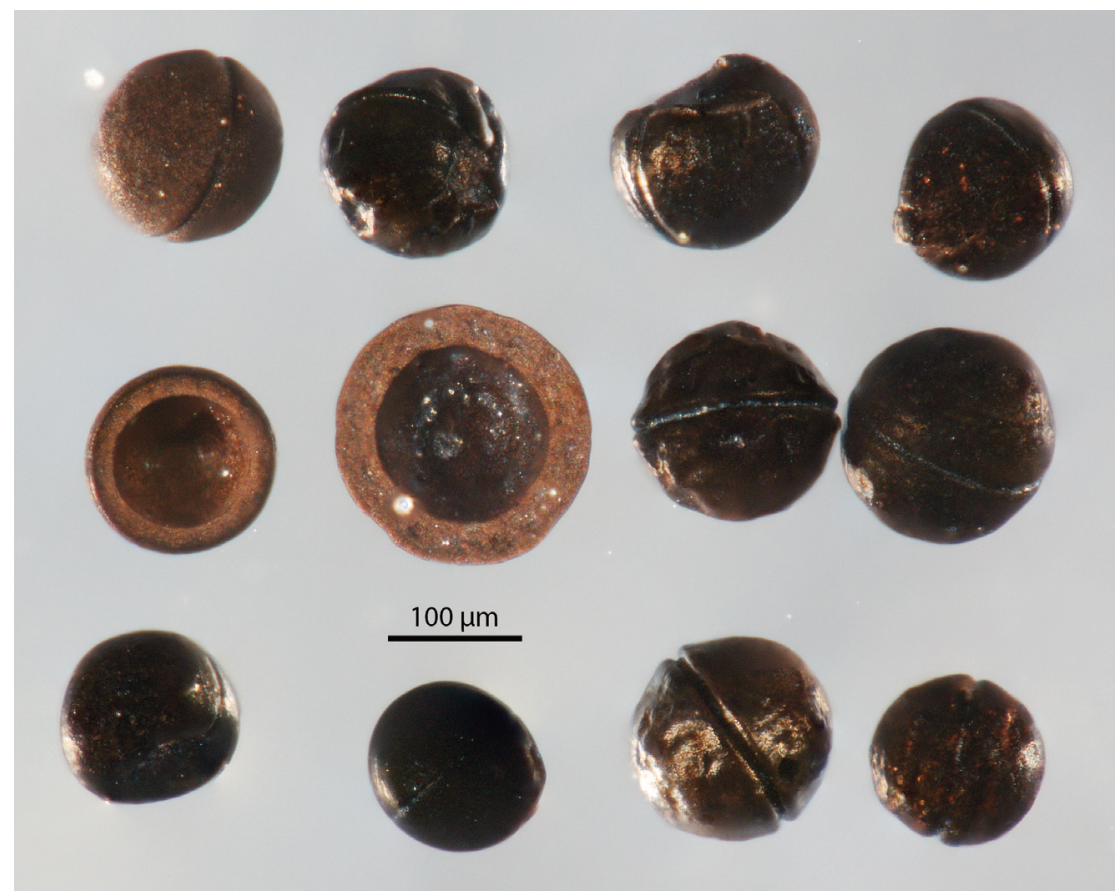

Fig. 3. Light microscopy images of Vikisphaera kundana gen. et sp. nov. from the type locality, Viki core, depth 360.9-361.1 m, sample OM8-4, Kunda Regional Stage, lower Darriwilian.

Material. More than a thousand specimens from ten sections in Estonia, Sweden, Latvia and northwestern Russia (Fig. 1). Localities in Estonia: Kaugatuma drill core, depth 456.6-458.8 m; Velise drill core, 231.55$233.40 \mathrm{~m}$; Viki drill core, 360.75-361.25 m (Hints et al. 2014); Rapla drill core, 184.8-185.5 m; Aseri cliff, uppermost $0.7 \mathrm{~m}$ of the Kunda Regional Stage in three samples; Jägala waterfall section (Nõlvak et al. 2019), $2 \mathrm{~m}$ above the base of the Kunda Regional Stage in one sample; Uuga cliff, within the topmost $0.3 \mathrm{~m}$ of the Kunda Regional Stage (Tammekänd et al. 2010; Hints et al. 2012). Localities in other regions: File Haidar drill core, Gotland, Sweden, 341.61-341.70 m (see faunal log in Grahn \& Nõlvak 2010, fig. 21); Baldone drill core, Latvia, 898.9-900.9 m (two samples from the uppermost Baldone Formation, Kunda Regional Stage); Osmino-111 drill core, northwestern Russia, $134.3 \mathrm{~m}$.

Diagnosis. As for the genus.

Description. Spherical hollow shells, 85-200 $\mu \mathrm{m}$ in diameter, dark brown to nearly black in colour, composed of organic substance that is superficially similar to the material of chitinozoans and scolecodonts. The outer surface of the shell is generally smooth and glossy, but sometimes shows slightly undulating or vermiculate finish (Fig. 4B, E). The shell material is brittle and if compressed, the shells display cracks and angular breakage (Fig. 4C-G).
Most specimens have a well-defined diagnostic equatorial groove that divides the shell into two hemispherical parts. Two small ridges or folds occur in the bottom of the groove (e.g. Fig. 4D, F) or close to it. In few specimens, the groove is less clearly developed, but its location is still marked by tiny ridges. A significant proportion of specimens are split into two halves, most commonly along the groove (Fig. 4H, K, M). The inner surface of the shell is smooth, showing no indication or specific features corresponding to the groove on the outer surface (Fig. 4L). The shell wall is somewhat thinner below the groove, but otherwise showing no specific structure.

The shell wall varies notably in both thickness and structure. It is very thin and compact in some specimens, with few closed pores usually less than $1 \mu \mathrm{m}$ in diameter (Fig. 4J). The minimum measured shell thickness in such specimens is $c a 3.5 \mu \mathrm{m}$ (Fig. 4F). The other extreme is a very thick shell wall (a maximum of $27 \mu \mathrm{m}$ ), composed of porous material or spongy framework (Fig. 4I, M). In such specimens, the outer and inner parts of the wall close to the inner and outer surfaces are somewhat more compact. An intermediate type of the shell wall is illustrated in Fig. 4L, having an average thickness of $10-15 \mu \mathrm{m}$ and consisting of more compact material with fewer and smaller pores in the outer half of the wall, whereas the inner part has a spongy framework with large voids $\mathrm{ca}$ 1$5 \mu \mathrm{m}$ in size (Fig. 4L). 


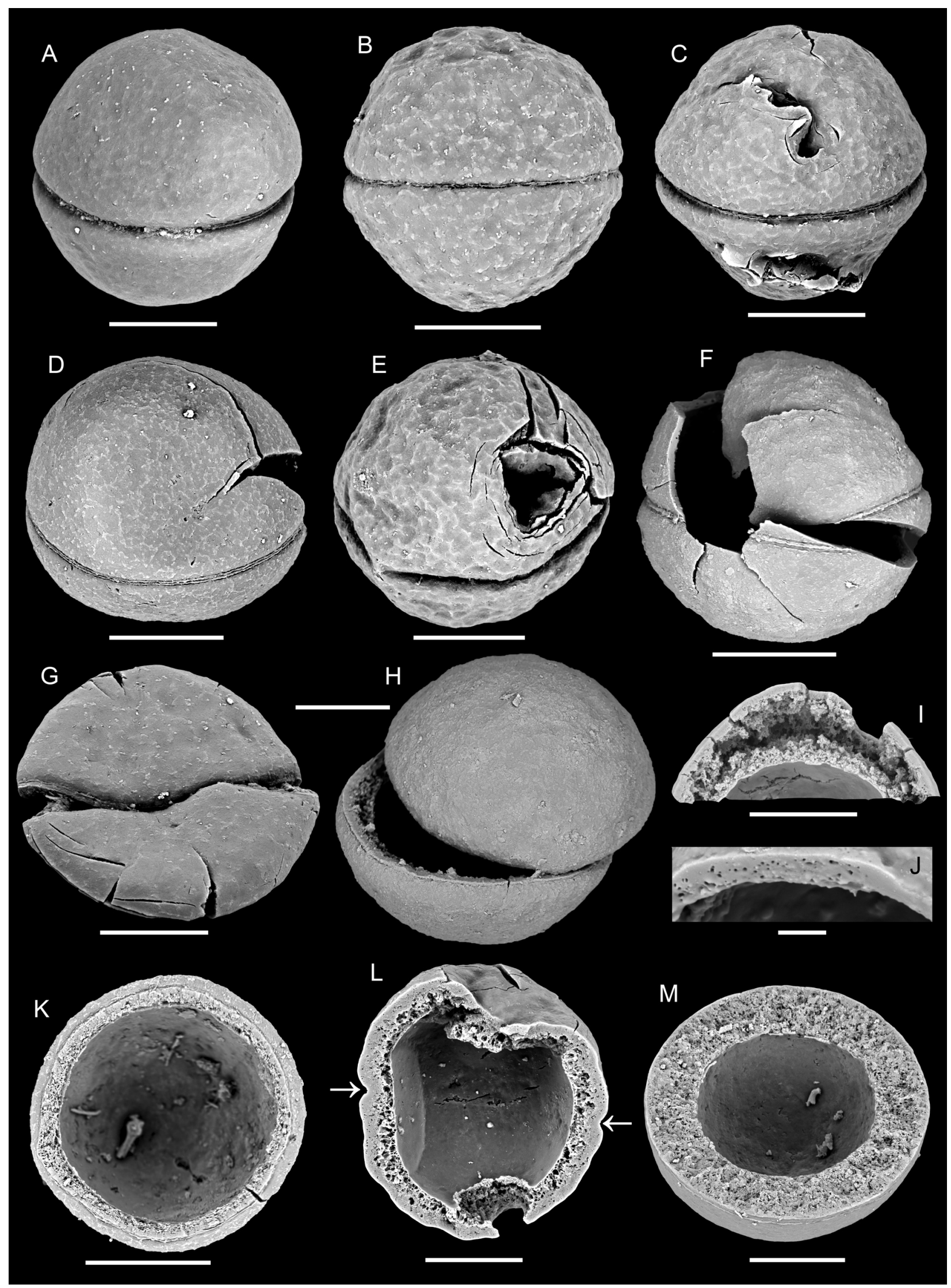


Measurements. A total of 153 complete specimens from a single sample (OM8-4) from the type locality were measured. Their diameter ranges from 85 to $185 \mu \mathrm{m}$, with a mean and median values of 138.6 and $139.0 \mu \mathrm{m}$, respectively. The data are normally distributed and nearly $80 \%$ of the specimens share a diameter between 115 and $155 \mu \mathrm{m}$ (Fig. 5). The coefficient of variation, which is calculated from the standard deviation and mean of the data set is $11.85 \%$. The largest specimens in other samples exceptionally reach $200 \mu \mathrm{m}$ in diameter.

Variability. In addition to variation in the size of the shells, the thickness and structure of the shell wall are highly variable in Vikisphaera kundana. We suggest that this feature is related to the development of the related organism and not an indication of the presence of multiple taxa within the studied collection.

Occurrence. Lower Darriwilian (Middle Ordovician) of Baltoscandia.

Remarks. The biological affinity and distribution of Vikisphaera kundana are further discussed below.

\section{DISCUSSION AND CONCLUSIONS}

\section{Notes on the distribution}

The geographical distribution of Vikisphaera is wide within the Baltoscandian Basin (Fig. 1). In the Viki core section, the type locality, Vikisphaera was first discovered in abundance from a single large sample (No. OM8-4 from 360.9-361.09 m, $\sim 800 \mathrm{~g}$ ) collected for conodonts, chitinozoans and scolecodonts (Põldvere 2010; Hints et al. 2014). In order to reveal its stratigraphic distribution in more detail, 22 bed-by-bed samples of 30-60 g were studied from below and above the first productive sample and all recovered specimens of Vikisphaera were counted (Fig. 6). The results show a 0.5 -m-thick total range with a 0.4-m-thick well-constrained acme where the maximum abundance of Vikisphaera reaches 6.5 specimens per gram of rock. In the lowermost and uppermost productive samples, only few specimens were found (Fig. 5). The conodont fauna at a core depth of 360.9-361.09 $\mathrm{m}$ includes Yangtzeplacognathus cf. crassus, indicating the
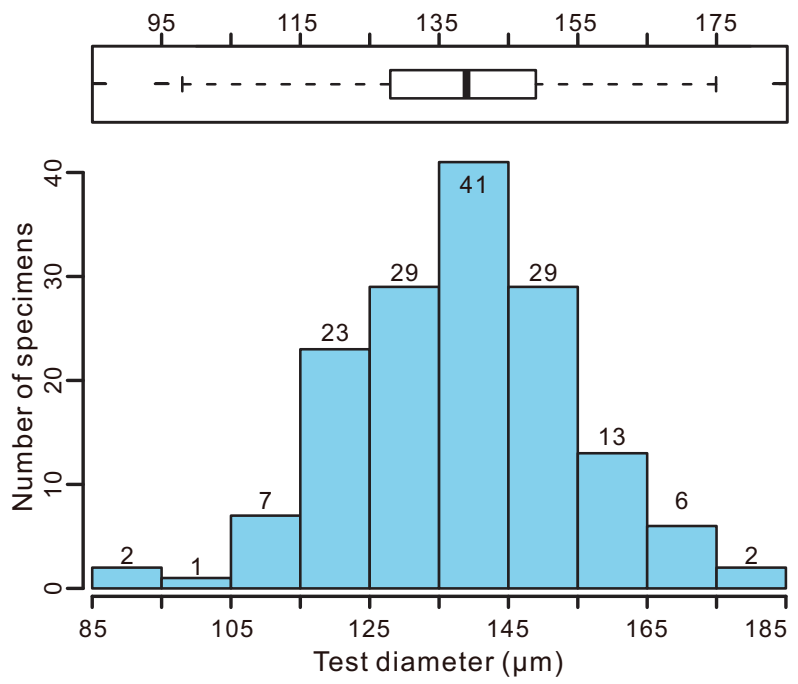

Fig. 5. Histogram of the average diameter of Vikisphaera kundana gen. et sp. nov. from the type locality, Viki core, depth 360.9$361.1 \mathrm{~m}$, sample OM8-4.

Y. crassus Zone and suggesting that Vikisphaera occurs in the lower to middle part of the Kunda Regional Stage (Männik \& Viira 2012; Lindskog et al. 2017) in the Viki core. Chitinozoans from the same sample indicate the Cyathochitina regnelli Zone (Põldvere 2010).

Considering conodont biostratigraphy and regional lithostratigraphic correlations, Vikisphaera has been recognized in somewhat younger strata in some localities. For instance, in the Osmino-111 core, Vikisphaera was recorded in a single sample from the upper part of the Kunda Regional Stage on the basis of unpublished data of Silvi Mägi. In the Jägala waterfall section, Vikisphaera occurs in a similar stratigraphic position: Loobu Formation, middle and/or upper part of the stage (Nõlvak et al. 2019). In the Uuga cliff, the productive interval belongs to the Pakri Formation and corresponds to the Cyathochitina regnelli chitinozoan Zone and Eoplacognathus pseudoplanus conodont Zone (Hints et al. 2012), the upper part of the Kunda Regional Stage. In the Kaugatuma core, Vikisphaera occurs in the upper $c a 2.2 \mathrm{~m}$ interval (eight consecutive samples) in the 6.6-m-thick Kunda Regional Stage. The conodont zonation of this interval is unknown, but according to unpublished data by

Fig. 4. SEM micrographs of selected specimens of Vikisphaera kundana gen. et sp. nov., all from the Kunda Regional Stage, lower Darriwilian. A-J, L, M from the type locality, Viki core, depth 360.9-361.1 m, sample OM8-4; K from the File Haidar core, Gotland, Sweden, depth 341.61-341.70 m. A, B, three-dimensionally preserved whole specimens; C-G, broken or deformed whole specimens; $\mathbf{H}-\mathbf{M}$, specimens split into halves, showing variable thickness of the shell wall. H, K, M split along the groove, $\mathbf{L}$ split into halfsphere perpendicular to the equatorial groove, the location of the groove in cross-section is indicated by arrows. Specimen numbers: A, GIT 742-1, holotype; B, GIT 742-2; C, GIT 742-3; D, GIT 742-4; E, GIT 742-5; F, GIT 742-6; G, GIT 742-7; H, GIT 742-8; I, GIT 742-9; J, GIT 742-10; K, GIT 742-11; L, GIT 742-12; M, GIT 742-13. The scale bar corresponds to $50 \mu \mathrm{m}$, except in J, where it corresponds to $10 \mu \mathrm{m}$. 


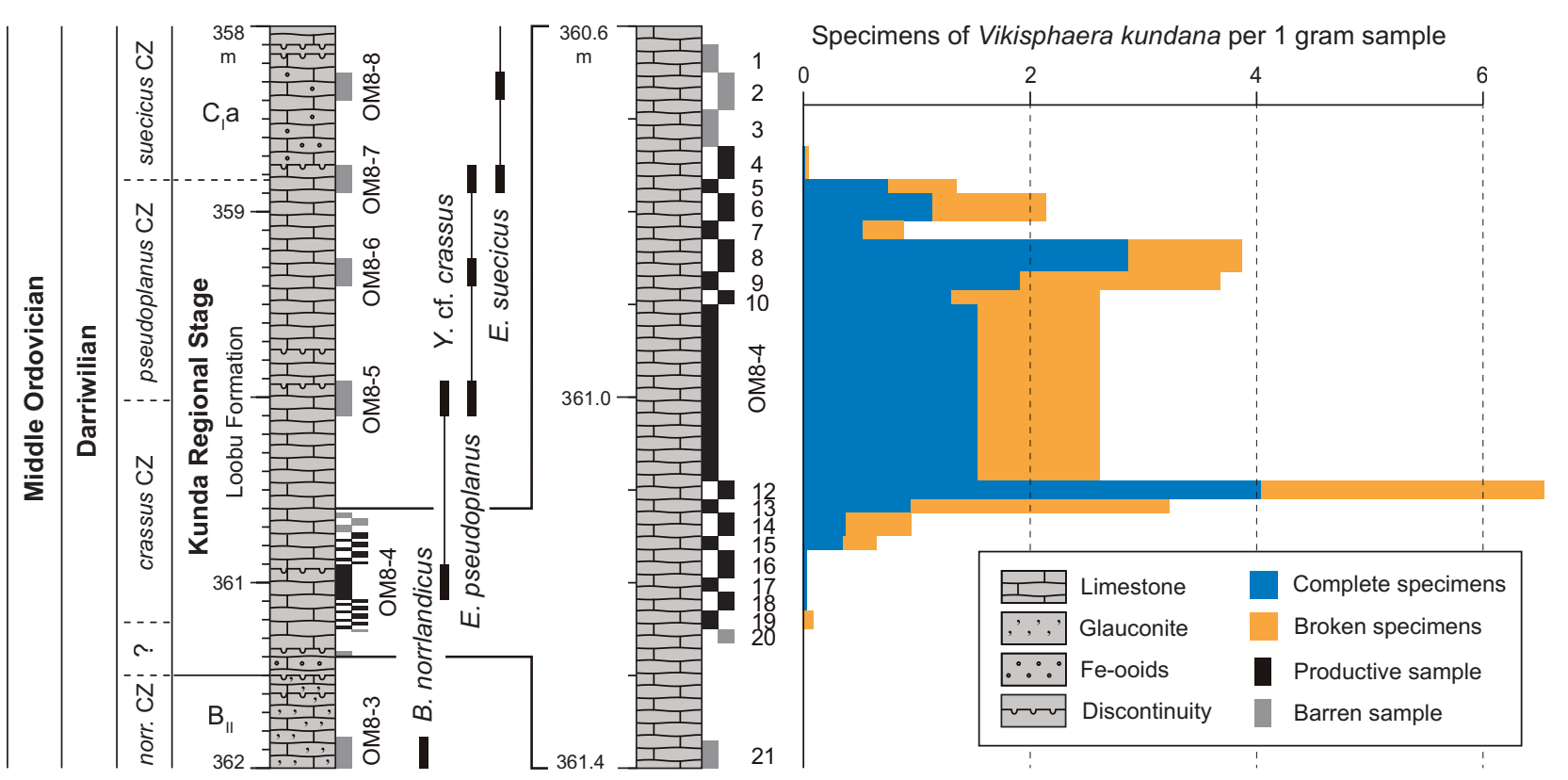

Fig. 6. Range of Vikisphaera kundana in the type locality, Viki drill core, western Estonia. Stratigraphy of the core according to Hints et al. (2014) and Põldvere (2010). Abbreviations: CZ, conodont zone; norr., norrlandicus; $\mathrm{B}_{\mathrm{II}}$, Volkhov Regional Stage; $\mathrm{C}_{\mathrm{I}} \mathrm{a}$, Aseri Regional Stage.

Viive Viira, it is below the appearance of the zonal index Eoplacognathus suecicus. Other occurrences of Vikisphaera are less well dated, but Kunda age can be inferred from macrofossil data, chitinozoan biostratigraphy or regional geological and stratigraphic constraints (Figs 2, 6).

It can be concluded that the stratigraphic distribution of Vikisphaera spans at least two conodont zones within the Kunda Regional Stage, lower Darriwilian. According to recent estimates, the Kunda Regional Stage corresponds to ca 3-5 Ma (Lindskog et al. 2017; Goldman et al. 2020), suggesting that the known temporal range of Vikisphaera is a few million years. Such a restricted stratigraphic distribution implies its biostratigraphic utility. However, the short range also poses a question whether the organism related to Vikisphaera had a similarly short range or perhaps the preservation of the fossils was related to unique depositional or diagenetic conditions present in the Kunda Age in Baltoscandia. Alternatively, the short range of Vikisphaera in Baltoscandia could be explained by a temporally constrained immigration event from an unknown source area where the fossil is yet to be discovered. For instance, the zonal conodont $Y$. crassus cooccurring with Vikisphaera is thought to represent an immigrant from the South China palaeoplate where the Yangtzeplacognathus lineage evolved (Zhang 1998).

It is also interesting to note that the stratigraphic distribution of Vikisphaera largely coincides with the temporal range of fossil meteorites found in Baltoscandia, descending from the breakup of the L-chondrite parent body at ca $468 \mathrm{Ma}$ (Lindskog et al. 2017). This meteorite shower has been linked to global environmental changes and the onset of the GOBE (Schmitz et al. 2007, 2019). Even though such connection has been questioned by other authors (Lindskog et al. 2017), the fact that the abundance of meteoritic material coincides with specific facies, biotic events and the range of Vikisphaera remains puzzling.

Another feature of the Kunda Regional Stage worth mentioning is the highest average abundance of phosphorus in the shallow shelf part of the Baltoscandian Basin (Kiipli et al. 2010) and common phosphatization of sediments and hardgrounds, as evidenced also by the samples containing Vikisphaera. One may hypothesize that phosphatization may have enhanced the fossilization potential of Vikisphaera in this particular stratigraphic interval. Nevertheless, the organic-walled nature of the shell of Vikisphaera and relatively high phosphate contents recorded through the Dapingian and Darriwilian in Baltoscandia beyond the range of Vikisphaera make this possibility unlikely.

\section{Biological affinities}

Vikisphaera co-occurs with two other microfossil groups that may be of similar size and general shape. The black organic-walled chitinozoans of the genus Desmochitina have a rounded vesicle and are common in Ordovician 
strata. A diagnostic feature of all chitinozoans is an opening in the shell, the aperture, originally closed by the operculum or prosome (Paris et al. 1999). The vesicle wall of most chitinozoans is relatively thin compared to that of Vikisphaera, and if it is thicker like in e.g. Desmochtina? bulla (cf. Paris \& Mergl 1984, fig. P1. 1:1-4), there is little intraspecific variation in wall thickness in chitinozoans. Chitinozoans have radial symmetry, whereas Vikisphaera may also be viewed as bilaterally symmetrical along the equatorial groove in the shell. Collectively these differences, especially the lack of the aperture, make close relationships between Vikisphaera and chitinozoans very unlikely even though functional analogy of the organicwalled shell of both groups should not be excluded. The lack of opening(s) in Vikisphaera also excludes the possibility that it is related to foraminiferans, testate amoebae or comparable protists.

Another group of similar organic-walled microfossils, co-occurring with Vikisphaera, is the prasinophycean green algae Tasmanites (Eisenack 1963). This genus is often abundant in Darriwilian strata of the study area, has the same size range and usually dark brown to black colour as Vikisphaera. Thus, specimens of Vikisphaera may be misidentified as Tasmanites if using insufficient magnification not resolving the diagnostic equatorial groove. This superficial similarity has probably been the main reason why the specimens of Vikisphaera in the existing microfossil collections were initially overlooked. Prasinophyceans, however, lack the equatorial groove and their shell wall is composed of more homogeneous material, less variable in thickness, and contains pores and sometimes a larger aperture (Guy-Ohlson 1996).

Rubinstein \& Vajda (2019) recently reported the occurrence of cryptospores and trilete spores in the Darriwilian to Katian strata of Baltica. Some of the proposed spores are similar in shape to the genus Leiosphaeridia. Compared to Vikisphaera, the supposed spores are clearly smaller and with a thinner wall, light yellow to brown in colour and lacking the distinctive groove.

As a rounded organic-walled microfossil of unknown biological origin, Vikisphaera could be attributed to the Acritarcha according to the original definition of this term (Evitt 1963; Servais et al. 1996). Typical acritarchs have processes or outgrowths from the spherical chamber (acanthomorphs), but many smooth forms (sphaeromorphs) exist too (Strother 1996). Fossils, described to date as acritarchs, may indeed include taxa with various affinities, but most of them were likely cysts of photosynthesizing protists and represent the main fossil evidence of early Palaeozoic phytoplankton (Servais et al. 1996, 2016). No acritarchs described so far possess an equatorial groove on the test surface similar to that in Vikisphaera, but an equatorial carina surrounding the whole test is the diagnostic feature of the rare Late
Ordovician acanthomorph acritarch genus Carinatosphaeridium from Baltoscandia (Eiserhardt 1984, 1992). However, dinoflagellates (photosynthesizing protists) have organic-walled tests featuring the cingulum - a long furrow around the test superficially resembling the groove of Vikisphaera. Dinoflagellate resting cysts are common microfossils from the Triassic onwards, but molecular evidence suggests that closely similar organisms existed already in the Cambrian (Moldowan \& Talyzina 1998). Some recent dinoflagellates, for instance Alexandrium tamutum (Menezes et al. 2018, fig. 3) display overall similarity with Vikisphaera, but there are important differences as well. First, the dinoflagellate tests are characterized by the tabular structure of the wall and a furrow perpendicular to the cingulum (sulcus). These features may be missing in the cyst stage, but then also the cingulum is absent. Secondly, dinoflagellate tests are commonly thin-walled, not globular and possess additional features like the archaeopyle that are not present in Vikisphaera. Most recent and fossil dinoflagellates are also much smaller than Vikisphaera, 30$80 \mu \mathrm{m}$ in diameter (Finkel et al. 2007). Thus, dinoflagellate affinity can be considered unlikely, and we emphasize the clear distinction between Vikisphaera and typical acanthomorph acritarchs that are commonly considered to represent Palaeozoic microphytoplankton.

There are few other enigmatic organic-walled microfossils that could be compared with Vikisphaera. Such are, for instance, the enigmatic organic-walled incertae sedis microfossils with cell-like wall structure reported by Heuse et al. (1996), but in details no close similarity and relationship could be identified.

Another plausible way to explain the nature of Vikisphaera specimens is to consider them not as shells of small organisms but as eggs or other developmental stages of metazoans, similarly to a common interpretation of the Chitinozoa (Paris \& Nõlvak 1999). According to Liang et al. (2019), it was unlikely that chitinozoans were eggs because of their large size variation. The size variation of Vikisphaera is also rather wide - with the largest specimens being twice the size of the smallest ones and the coefficient of variation reaching $\mathrm{ca} 12 \%$ - but falls within the range of egg-size variation of modern aquatic metazoans, notably molluscs and echinoderms (Liang et al. 2019). Another noteworthy aspect of Vikisphaera is that the ratio between whole specimens and those split into halves varies widely from sample to sample, being ca 30-75\% (Fig. 6). This suggests that if Vikisphaera were eggs, many did not live to hatching. However, the overproduction of eggs and high egg mortality rate when building up a 'sediment egg bank' is not uncommon for a variety of modern zooplankton taxa (Hairston et al. 1995) and could explain the relatively high percentage of intact spheres in Vikisphaera too. 
Morphologically the closest fossils to Vikisphaera are described from the early Cambrian of northwestern Canada as Olivooides and interpreted as metazoan eggs and embryos (Pyle et al. 2006). These fossils are preserved via phosphatization, displaying a globular shape and variable size from ca 0.4 to $1.0 \mathrm{~mm}$. Despite being considerably larger than Vikisphaera, some specimens of Olivooides sp. have a strikingly similar wall structure with spongy material and large variation in wall thickness (cf. Pyle et al. 2006, figs $2.15,2.16$ ). However, it is not entirely clear to what extent the secondary phosphatization might have influenced the wall thickness and structure of the Canadian material. In some specimens, a groove across the fossils is present (Pyle et al. 2006, figs 2.6, 2.8). It is interpreted by the original authors as a unipolar furrow separating the blastomeres of an embryo and cannot be directly compared with the groove on the outer side of the shell in Vikisphaera. A thorough discussion of Olivooides and other Cambrian eggs and embryos is provided by e.g. Bengtson \& Zhao (1997), Mathur et al. (2014) and Steiner et al. (2014). Compared to Vikisphaera, the Cambrian material is usually much larger and often shows some forms of embryonal development. The Cambrian embryos often co-occur with small shelly fossils and may, in some cases, be directly related to them. Fossil embryos and putative spherical eggs are well known also from the Ediacaran (Cohen et al. 2009; Yin \& Zhu 2012; Yin et al. 2018, 2020), some of them with overlapping and superficially similar wall structure and thickness to that observed in Vikisphaera. Ediacaran embryos may have an external groove (Yin et al. 2020), but this is helical not equatorial.

The exact systematic position of Ediacaran and Cambrian eggs and embryos has mostly remained unresolved, but referring to metazoans or bilaterians, or holozoans (Yin et al. 2020). Phosphatic eggs and embryos are less common in the later geological record and considering the major evolutionary events between the early Cambrian and Middle Ordovician, Vikisphaera could not be directly linked to e.g. Olivooides or any other previously described genus.

The temporal range of Vikisphaera coincides with the major pulse of the GOBE on Baltica and worldwide (Hints et al. 2010; Rasmussen et al. 2016, 2019; Kröger et al. 2019; Harper et al. 2020). The early Darriwilian rocks in Baltoscandia are rich in various representatives of shelly faunas such as brachiopods, trilobites, bryozoans, cephalopods, gastropods, echinoderms and ostracods (Männil 1966). Graptolites were widespread too, albeit relatively rare in shallow shelf settings, whereas polychaete worms evidenced by scolecodonts thrived in proximal facies and diversified rapidly during the early Darriwilian (Hints 2000; Hints \& Eriksson 2007; Eriksson et al. 2016). Life cycles of all these groups likely included egg and larval stages but reports of fossil eggs from the Ordovician are extremely rare. Hence direct comparison between eggs of all mentioned groups and Vikisphaera is impossible at present, but some examples can be discussed.

The Middle Ordovician organic-walled microfossil Clistrocystis (Kozłowski 1959), commonly attached to graptolite stipes, has been interpreted to represent cephalopod eggs (Kozłowski 1965). Despite having a rather different morphology and larger size, the shell material of Clistrocystis is similar to that of Vikisphaera. It is noteworthy that the Kunda Regional Stage is known as 'Orthoceratite Limestone' in Baltoscandia, referring to the high abundance and diversity of cephalopods (Kröger 2012). Several cephalopod shells are present even in a core sample from the Viki type locality with most abundant Vikisphaera specimens (sample OM8-4; https://geocollections.info/file/125797). However, the size of recent and fossil cephalopod eggs is 10 to 100 times larger than the shells of Vikisphaera (Laptikhovsky et al. 2018), and cephalopods are common also in the overlying strata where Vikisphaera has not been reported. Thus, cephalopods could unlikely be the parent organism of Vikisphaera.

Putative trilobite eggs from the Ordovician of Laurentia (Hegna et al. 2017) show a similar size range as Vikisphaera, but they are clearly ovoid in shape. Fine morphological details of these pyritic fossils are not preserved and do not allow further comparison (possibly the objects are faecal pellets and not eggs, cf. Toom et al. 2020). Undisputable eggs and embryos of Ordovician and Silurian ostracods were reported by Siveter et al. (2007, 2014). These structures, too, have an elongated rather than spherical shape and their size is several times larger than that of Vikisphaera. The state of preservation limits direct comparison of fine morphological details.

However, arthropods include other plausible candidates for the parent organism of Vikisphaera. For instance, copepod crustaceans produce diapause eggs in the same size range as Vikisphaera, sometimes with a thick chitinous casing to ensure surviving desiccation and passage through the guts of predators (Hairston et al. 1995; Winding Hansen 2019). The fossil record of copepods is extremely scarce due to their low fossilization potential, but molecular data suggest the emergence of copepods in the Cambrian and separation of major lineages at ca $460 \mathrm{Ma}$ ago (Selden et al. 2010). Probable copepod fossils have been reported from the Cambrian (Harvey \& Pedder 2013) but are thus far unknown from the Ordovician. Branchiopods (water fleas, fairy shrimps, clam shrimps) are another group of small crustaceans producing diapause eggs, often called cysts, overlapping in size with Vikisphaera. The morphology of extant branchiopod eggs with references to fossil material has been analysed by e.g. Shen \& Huang (2008). These 
authors identified several rather different egg-shell surface types in clam shrimps alone, from ridge- and hairy- to ripple-type, the last one resembling the outer surface of some specimens of Vikisphaera. The cyst shell thickness and spongy structure of some extant anostracan branchiopods (Hegna \& Lazo-Wasem 2010; Yin et al. 2018) are similar to the shell wall of Vikisphaera. However, to our knowledge, a huge variation in wall thickness and the presence of the equatorial groove have not been identified in modern branchiopods (or other crustaceans). The hitherto known fossilized branchiopod eggs are too poorly preserved to allow direct comparison with Vikisphaera, except for their overlapping size range (Shen \& Huang 2008). Thus, even though several small crustaceans could be plausible parents of Vikisphaera, no direct evidence to support this is available at present.

As a conclusion, we hypothesize that Vikisphaera is a more convincing candidate for fossil eggs than chitinozoans, but its parent organism could not be identified among the shelly fossil groups common in the Kunda Regional Stage in Baltoscandia. Perhaps it was a marine bilaterian with low fossilization potential, but before there is solid evidence to confirm this view, Vikisphaera could be considered as an acritarch - an organic-walled microfossil of unknown affinity.

Acknowledgements. The authors are grateful to Thomas Servais, Tom Harvey and Olev Vinn who acted as reviewers and whose suggestions improved the manuscript considerably. We also thank the associate editor Tõnu Meidla for many useful comments, and Marco Vecoli and Charles H. Wellman for discussions on the possible affinities of Vikisphaera. Mairy Tammekänd and Riina Klaas are acknowledged for their help in microfossil preparation and picking. Viive Viira provided information on conodont biostratigraphy. The study was supported by the Estonian Research Council grants and the National Natural Science Foundation of China (grant 41972015) and is a contribution to the IGCP Projects 653 'The Onset of the Great Ordovician Biodiversification Event' and 735 'Rocks and the Rise of Ordovician Life'. The publication costs of this article were partially covered by the Estonian Academy of Sciences.

\section{REFERENCES}

Achab, A. \& Paris, F. 2007. The Ordovician chitinozoan biodiversification and its leading factors. Palaeogeography, Palaeoclimatology, Palaeoecology, 245, 5-19.

Ainsaar, L., Kaljo, D., Martma, T., Meidla, T., Männik, P., Nõlvak, J. \& Tinn, O. 2010. Middle and Upper Ordovician carbon isotope chemostratigraphy in Baltoscandia: A correlation standard and clues to environmental history. Palaeogeography, Palaeoclimatology, Palaeoecology, 294, 189-201.

Bengtson, S. \& Zhao, Y. 1997. Fossilized metazoan embryos from the earliest Cambrian. Science, 277, 1645-1648.
Bergström, S. M., Chen, X., Gutiérrez-Marco, J. C. \& Dronov, A. 2009. The new chronostratigraphic classification of the Ordovician System and its relations to major regional series and stages and to $\delta^{13} \mathrm{C}$ chemostratigraphy. Lethaia, 42, 97107.

Bergström, S. M., Calner, M., Lehnert, O. \& Noor, A. 2011. A new upper Middle Ordovician-Lower Silurian drillcore standard succession from Borenshult in Östergötland, southern Sweden: 1. Stratigraphical review with regional comparisons. GFF, 133, 149-171.

Bergström, S. M., Ahlberg, P., Maletz, J., Lundberg, F. \& Joachimski, M. M. 2018. Darriwilian (Middle Ordovician) chemostratigraphy linked to graptolite, conodont and trilobite biostratigraphy in the Fågelsång-3 drill core, Scania, Sweden. GFF, 140, 229-240.

Cocks, L. R. M. \& Torsvik, T. H. 2005. Baltica from the late Precambrian to mid-Palaeozoic times: The gain and loss of a terrane's identity. Earth-Science Reviews, 72, 39-66.

Cocks, L. R. M. \& Torsvik, T. H. 2020. Ordovician palaeogeography and climate change. Gondwana Research, S1342937X20302756.

Cohen, P. A., Knoll, A. H. \& Kodner, R. B. 2009. Large spinose microfossils in Ediacaran rocks as resting stages of early animals. Proceedings of the National Academy of Sciences, 106, 6519-6524.

Eisenack, A. 1931. Neue Mikrofossilien des baltischen Silurs. I. Paläontologische Zeitschrift, 13, 74-118.

Eisenack, A. 1932. Neue Mikrofossilien des baltischen Silurs. II. Paläontologische Zeitschrift, 14, 257-277.

Eisenack, A. 1934. Neue Mikrofossilien des baltischen Silurs. III. und neue Mikrofossilien des böhmischen Silurs. I. Paläontologische Zeitschrift, 16, 52-76.

Eisenack, A. 1937. Was ist Melanostrophus? Zeitschrift für Geschiebeforschung und Flachlandsgeologie, 13, 100-104.

Eisenack, A. 1963. Über einige Arten der Gattung Tasmanites Newton 1875. Grana Palynologica, 4, 203-216.

Eiserhardt, K.-H. 1984. Carinatosphaeridium n. g. (Acritarcha) aus einem Öjlemyr-Flintgeschiebe Gotlands (ob. Ordoviz.). Neues Jahrbuch für Geologie und Paläontologie - Monatshefte Jg., 9, 521-528.

Eiserhardt, K.-H. 1992. Die Acritarchen des Öjlemyrflintes. Palaeontographica Abt. B, 226, 1-132.

Eriksson, M. E., Lindskog, A., Servais, T., Hints, O. \& Tonarová, P. 2016. Darriwilian (Middle Ordovician) worms of southern Sweden. GFF, 138, 502-509.

Evitt, W. R. 1963. A discussion and proposals concerning fossil dinoflagellates, hystrichospheres, and acritarchs, I. Proceedings of the National Academy of Sciences, 49, 158164.

Finkel, Z. V., Sebbo, J., Feist-Burkhardt, S., Irwin, A. J., Katz, M. E., Schofield, O. M. E., Young, J. R. \& Falkowski, P. G. 2007. A universal driver of macroevolutionary change in the size of marine phytoplankton over the Cenozoic. Proceedings of the National Academy of Sciences, 104, 20416-20420.

Goldman, D., Sadler, P. M. \& Leslie, S. A. 2020. Chapter 20. The Ordovician Period. In Geologic Time Scale 2020. Volume 2 (Gradstein, F. M., Ogg, J. G., Schmitz, M. D. \& Ogg, G. M., eds), pp. 631-694. Elsevier.

Grahn, Y. \& Nõlvak, J. 2010. Swedish Ordovician Chitinozoa and biostratigraphy: a review and new data. Palaeontographica Abt. B, 283, 1-71. 
Grahn, Y. \& Paris, F. 2011. Emergence, biodiversification and extinction of the chitinozoan group. Geological Magazine, 148, 226-236.

Guy-Ohlson, D. 1996. Chapter 7B. Prasinophycean algae. In Palynology: Principles and Applications (Jansonius, J. \& McGregor, D. C., eds), pp. 181-189. American Association of Stratigraphic Palynologists Foundation.

Hagen-Peter, G., Wang, Y., Hints, O., Prave, A. R. \& Lepland, A. 2021. Late diagenetic evolution of Ordovician limestones in the Baltoscandian basin revealed through trace-element mapping and in situ U-Pb dating of calcite. Chemical Geology, 585, 120563.

Hairston, N. G., Van Brunt, R. A., Kearns, C. M. \& Engstrom, D. R. 1995. Age and survivorship of diapause eggs in a sediment egg bank. Ecology, 76, 1706-1711.

Harper, D. A. T. 2006. The Ordovician biodiversification: Setting an agenda for marine life. Palaeogeography, Palaeoclimatology, Palaeoecology, 232, 148-166.

Harper, D. A. T., Cascales-Miñana, B. \& Servais, T. 2020. Early Palaeozoic diversifications and extinctions in the marine biosphere: a continuum of change. Geological Magazine, $157,5-21$.

Harvey, T. H. P. \& Pedder, B. E. 2013. Copepod mandible palynomorphs from the Nolichucky Shale (Cambrian, Tennessee): implications for the taphonomy and recovery of small carbonaceous fossils. PALAIOS, 28, 278-284.

Hegna, T. A. \& Lazo-Wasem, E. A. 2010. Branchinecta brushi n. sp. (Branchiopoda: Anostraca: Branchinectidae) from a Volcanic Crater in Northern Chile (Antofagasta Province): A New Altitude Record for Crustaceans. Journal of Crustacean Biology, 30, 445-464.

Hegna, T. A., Martin, M. J. \& Darroch, S. A. F. 2017. Pyritized in situ trilobite eggs from the Ordovician of New York (Lorraine Group): Implications for trilobite reproductive biology. Geology, 45, 199-202.

Heuse, T., Lehnert, O. \& Kraft, P. 1996. Organic-walled microfossils Incertae Sedis from the Ordovician of the Argentine Precordillera and Bohemia. Acta Universitatis Carolinae Geologica, 40, 425-439.

Hints, O. 2000. Ordovician eunicid polychaetes of Estonia and surrounding areas: review of their distribution and diversification. Review of Palaeobotany and Palynology, 113, $41-55$.

Hints, O. \& Eriksson, M. E. 2007. Diversification and biogeography of scolecodont-bearing polychaetes in the Ordovician. Palaeogeography, Palaeoclimatology, Palaeoecology, 245, 95-114.

Hints, O., Delabroye, A., Nõlvak, J., Servais, T., Uutela, A. \& Wallin, Å. 2010. Biodiversity patterns of Ordovician marine microphytoplankton from Baltica: Comparison with other fossil groups and sea-level changes. Palaeogeography, Palaeoclimatology, Palaeoecology, 294, 161-173.

Hints, O., Viira, V. \& Nõlvak, J. 2012. Darriwilian (Middle Ordovician) conodont biostratigraphy in NW Estonia. Estonian Journal of Earth Sciences, 61, 210-226.

Hints, O., Martma, T., Männik, P., Nõlvak, J., Põldvere, A., Shen, Y. \& Viira, V. 2014. New data on Ordovician stable isotope record and conodont biostratigraphy from the Viki reference drill core, Saaremaa Island, western Estonia. GFF, 136, 100-104.
Hints, O., Antonovitš, L., Bauert, G., Nestor, V., Nõlvak, J. \& Tammekänd, M. 2018. CHITDB: a database for documenting and analysing diversification of OrdovicianSilurian chitinozoans in the Baltic region. Lethaia, 51, 218227.

Kiipli, E., Kiipli, T., Kallaste, T. \& Ainsaar, L. 2010. Distribution of phosphorus in the Middle and Upper Ordovician Baltoscandian carbonate palaeobasin. Estonian Journal of Earth Sciences, 59, 247-255.

Kozłowski, R. 1959. Un microfossile énigmatique. Acta Palaeontologica Polonica, 4, 273-277.

Kozłowski, R. 1965. Oeufs fossiles des Céphalopodes? Acta Palaeontologica Polonica, 10, 3-9.

Kröger, B. 2012. The "Vaginaten": the dominant cephalopods of the Baltoscandian Mid Ordovician endocerid limestone. $G F F, \mathbf{1 3 4}, 115-132$.

Kröger, B., Franeck, F. \& Rasmussen, C. М. Ø. 2019. The evolutionary dynamics of the early Palaeozoic marine biodiversity accumulation. Proceedings of the Royal Society B: Biological Sciences, 286, 20191634.

Laptikhovsky, V., Nikolaeva, S. \& Rogov, M. 2018. Cephalopod embryonic shells as a tool to reconstruct reproductive strategies in extinct taxa: Cephalopod reproductive strategies. Biological Reviews, 93, 270-283.

Liang, Y., Hints, O., Luan, X., Tang, P., Nõlvak, J. \& Zhan, R. 2018. Lower and Middle Ordovician chitinozoans from Honghuayuan, South China: Biodiversity patterns and response to environmental changes. Palaeogeography, Palaeoclimatology, Palaeoecology, 500, 95-105.

Liang, Y., Bernardo, J., Goldman, D., Nõlvak, J., Tang, P., Wang, W. \& Hints, O. 2019. Morphological variation suggests that chitinozoans may be fossils of individual microorganisms rather than metazoan eggs. Proceedings of the Royal Society B: Biological Sciences, 286, 20191270.

Liang, Y., Hints, O., Tang, P., Cai, C., Goldman, D., Nõlvak, J., Tihelka, E., Pang, K., Bernardo, J. \& Wang, W. 2020. Fossilized reproductive modes reveal a protistan affinity of Chitinozoa. Geology, 48, 1200-1204.

Lindskog, A., Costa, M. M., Rasmussen, C. M. Ø., Connelly, J. N. \& Eriksson, M. E. 2017. Refined Ordovician timescale reveals no link between asteroid breakup and biodiversification. Nature Communications, 8, 14066.

Männik, P. \& Viira, V. 2012. Ordovician conodont diversity in the northern Baltic. Estonian Journal of Earth Sciences, 61, $1-14$.

Männil, R. 1966. Balti basseini areng ordoviitsiumis [Evolution of the Baltic Basin During the Ordovician]. Valgus Publishers, Tallinn, 200 pp. [in Russian].

Mathur, V. K., Shome, S., Nath, S. \& Babu, R. 2014. First record of metazoan eggs and embryos from early Cambrian Chert Member of Deo ka Tibba Formation, Tal Group, Uttarakhand Lesser Himalaya. Journal of the Geological Society of India, 83, 191-197.

Meidla, T. 1997. Kunda Stage. In Geology and Mineral Resources of Estonia (Raukas, A. \& Teedumäe, A., eds), pp. 64-66. Estonian Academy Publishers, Tallinn.

Menezes, M., Branco, S., Miotto, M. C. \& Alves-de-Souza, C. 2018. The Genus Alexandrium (Dinophyceae, Dinophyta) in Brazilian Coastal Waters. Frontiers in Marine Science, 5, $1-13$. 
Miller, M. A. 1996. Chapter 11. Chitinozoa. In Palynology: Principles and Applications. 1 (Jansonius, J. \& McGregor, D. C., eds), pp. 307-336. American Association of Stratigraphic Palynologists Foundation.

Moldowan, J. M. \& Talyzina, N. M. 1998. Biogeochemical evidence for dinoflagellate ancestors in the Early Cambrian. Science, 281, 1168-1170.

Nõlvak, J. \& Grahn, Y. 1993. Ordovician chitinozoan zones from Baltoscandia. Review of Palaeobotany and Palynology, 79, 245-269.

Nõlvak, J., Hints, O. \& Männik, P. 2006. Ordovician timescale in Estonia: recent developments. Proceedings of the Estonian Academy of Sciences, Geology, 54, 95-108.

Nõlvak, J., Liang, Y. \& Hints, O. 2019. Early diversification of Ordovician chitinozoans on Baltica: New data from the Jägala waterfall section, northern Estonia. Palaeogeography, Palaeoclimatology, Palaeoecology, 525, 14-24.

Paris, F. \& Mergl, M. 1984. Arenigian chitinozoans from the Klabava formation, Bohemia. Review of Palaeobotany and Palynology, 43, 33-65.

Paris, F. \& Nõlvak, J. 1999. Biological interpretation and paleobiodiversity of a cryptic fossil group: the 'Chitinozoan animal'. Geobios, 32, 315-324.

Paris, F., Grahn, Y., Nestor, V. \& Lakova, I. 1999. A revised chitinozoan classification. Journal of Paleontology, 73, 549570 .

Paris, F., Achab, A., Asseline, E., Chen, X.-H., Grahn, Y., Nõlvak, J., Obut, O., Samuelsson, J., Sennikov, N., Vecoli, M., Verniers, J., Wang, X.-F. \& Winchester-Seeto, T. 2004. Chitinozoa. In The Great Ordovician Diversification Event (Webby, B. D., Paris, F., Droser, M. \& Percival, I., eds), pp. 294-311. Columbia University Press, New York.

Pärnaste, H., Bergström, J. \& Zhiyi, Z. 2013. High resolution trilobite stratigraphy of the Lower-Middle Ordovician Öland Series of Baltoscandia. Geological Magazine, 150, 509-518.

Põldvere, A. (ed). 2010. Viki Drill Core. Estonian Geological Sections, Bulletin. 10. Geological Survey of Estonia, Tallinn, $56 \mathrm{pp}$.

Pyle, L. J., Narbonne, G. M., Nowlan, G. S., Xiao, S. \& James, N. P. 2006. Early Cambrian metazoan eggs, embryos, and phosphatic microfossils from northwestern Canada. Journal of Paleontology, 80, 811-825.

Rasmussen, C. M. Ø., Ullmann, C. V., Jakobsen, K. G., Lindskog, A., Hansen, J., Hansen, T., Eriksson, M. E., Dronov, A., Frei, R., Korte, C., Nielsen, A. T. \& Harper, D. A. T. 2016. Onset of main Phanerozoic marine radiation sparked by emerging Mid Ordovician icehouse. Scientific Reports, 6, 18884.

Rasmussen, C. M. Ø., Kröger, B., Nielsen, M. L. \& Colmenar, J. 2019. Cascading trend of Early Paleozoic marine radiations paused by Late Ordovician extinctions. Proceedings of the National Academy of Sciences, 116, 7207-7213.

Rubinstein, C. V. \& Vajda, V. 2019. Baltica cradle of early land plants? Oldest record of trilete spores and diverse cryptospore assemblages; evidence from Ordovician successions of Sweden. GFF, 141, 181-190.

Schmitz, B., Harper, D. A. T., Peucker-Ehrenbrink, B., Stouge, S., Alwmark, C., Cronholm, A., Bergström, S. M., Tassinari, M. \& Xiaofeng, W. 2007. Asteroid breakup linked to the Great Ordovician Biodiversification Event. Nature Geoscience, 1, 49-53.
Schmitz, B., Farley, K. A., Goderis, S., Heck, P. R., Bergström, S. M., Boschi, S., Claeys, P., Debaille, V., Dronov, A., van Ginneken, M., Harper, D. A. T., Iqbal, F., Friberg, J., Liao, S., Martin, E., Meier, M. M. M., Peucker-Ehrenbrink, B., Soens, B., Wieler, R. \& Terfelt, F. 2019. An extraterrestrial trigger for the mid-Ordovician ice age: Dust from the breakup of the L-chondrite parent body. Science Advances, 5, eaax4184.

Selden, P. A., Huys, R., Stephenson, M. H., Heward, A. P. \& Taylor, P. N. 2010. Crustaceans from bitumen clast in Carboniferous glacial diamictite extend fossil record of copepods. Nature Communications, 1, 50.

Servais, T., Brocke, R., Fatka, O., LeHerisse, A. \& Molyneux, S. G. 1996. Value and meaning of the term Acritarch. Acta Universitatis Carolinae Geologica, 40, 631-643.

Servais, T., Owen, A. W., Harper, D. A. T., Kröger, B. \& Munnecke, A. 2010. The Great Ordovician Biodiversification Event (GOBE): The palaeoecological dimension. Palaeogeography, Palaeoclimatology, Palaeoecology, 294, 99-119.

Servais, T., Martin, R. E. \& Nützel, A. 2016. The impact of the 'terrestrialisation process' in the late Palaeozoic: $p \mathrm{CO}_{2}, p \mathrm{O}_{2}$, and the 'phytoplankton blackout'. Review of Palaeobotany and Palynology, 224, 26-37.

Shen, Y. \& Huang, D. 2008. Extant clam shrimp egg morphology: taxonomy and comparison with other fossil branchiopod eggs. Journal of Crustacean Biology, 28, 352-360.

Siveter, D. J., Siveter, D. J., Sutton, M. D. \& Briggs, D. E. G. 2007. Brood care in a Silurian ostracod. Proceedings of the Royal Society B: Biological Sciences, 274, 465-469.

Siveter, D. J., Tanaka, G., Farrell, Ú. C., Martin, M. J., Siveter, D. J. \& Briggs, D. E. G. 2014. Exceptionally preserved 450-million-year-old Ordovician ostracods with brood care. Current Biology, 24, 801-806.

Steiner, M., Qian, Y., Li, G., Hagadorn, J. W. \& Zhu, M. 2014. The developmental cycles of early Cambrian Olivooidae fam. nov. (?Cycloneuralia) from the Yangtze Platform (China). Palaeogeography, Palaeoclimatology, Palaeoecology, 398, 97-124.

Strother, P. K. 1996. Chapter 5. Acritarchs. In Palynology: Principles and Applications (Jansonius, J. \& McGregor, D. C., eds), pp. 81-106. American Association of Stratigraphic Palynologists Foundation.

Tammekänd, M., Hints, O. \& Nõlvak, J. 2010. Chitinozoan dynamics and biostratigraphy in the Väo Formation (Darriwilian) of the Uuga Cliff, Pakri Peninsula, NW Estonia. Estonian Journal of Earth Sciences, 59, 25-36.

Toom, U., Vinn, O., Isakar, M., Madison, A. \& Hints, O. 2020. Small faecal pellets in Ordovician shelly fossils from Estonia, Baltoscandia. Estonian Journal of Earth Sciences, 69, 1-19.

Torsvik, T. H. \& Cocks, L. R. M. 2013. Chapter 2. New global palaeogeographical reconstructions for the Early Palaeozoic and their generation. Geological Society, London, Memoirs, 38, 5-24.

Verniers, J., Nestor, V., Paris, F., Dufka, P., Sutherland, S. \& Van Grootel, G. 1995. A global Chitinozoa biozonation for the Silurian. Geological Magazine, 132, 651-666.

Webby, B. D., Cooper, R. A., Bergström, S. M. \& Paris, F. 2004a. Stratigraphic framework and time slices. In The Great Ordovician Biodiversification Event (Webby, B. D., Paris, F., 
Droser, M. L. \& Percival, I. G., eds), pp. 41-47. Columbia University Press, New York.

Webby, B. D., Paris, F., Droser, M. L. \& Percival, I. G. 2004b. The Great Ordovician Biodiversification Event. Columbia University Press, New York, 484 pp.

Winding Hansen, B. 2019. Copepod Embryonic Dormancy: “An Egg Is Not Just an Egg”. The Biological Bulletin, 237, 145-169.

Yin, Z., Zhao, D., Pan, B., Zhao, F., Zeng, H., Li, G., Bottjer, D. J. \& Zhu, M. 2018. Early Cambrian animal diapause embryos revealed by X-ray tomography. Geology, 46, 387390.

Yin, Z., Sun, W., Liu, P., Zhu, M. \& Donoghue, P. C. J. 2020. Developmental biology of Helicoforamina reveals holozoan affinity, cryptic diversity, and adaptation to heterogeneous environments in the early Ediacaran Weng'an biota (Doushantuo Formation, South China). Science Advances, 6, eabb0083.

Yin, Z. J. \& Zhu, M. Y. 2012. New observations of the ornamented Doushantuo embryo fossils from the Ediacaran Weng'an Biota, South China. Bulletin of Geosciences, 87, 171-181.

Zhang, J. 1998. Middle Ordovician conodonts from the Atlantic Faunal Region and the evolution of key conodont genera. Meddelanden från Stockholms Universitetets Institution för Geologi och Geokemi, 298, 5-27.

\title{
Arvatavad Ordoviitsiumi ajastu mereloomade fossiilsed munad Baltoskandiast
}

\author{
Olle Hints, Jaak Nõlvak ja Yan Liang
}

Alam-Paleosoikumi läbilõige Baltoskandias on tuntud mikrofossiilide (akritarhid, kitiinikud, skolekodondid, konodondid jt) arvukuse, mitmekesisuse ja hea säilivuse poolest. Käesolevas töös on kirjeldatud Kesk-Ordoviitsiumi kihtidest uut mikrofossiilide perekonda ja liiki Vikisphaera kundana, millel on tumedast orgaanilisest ainest ekvatoriaalse vaoga ning ilma avausteta ümar kest diameetriga 90-200 $\mu \mathrm{m}$. Uut fossiili on leitud Eestist, Rootsist, Lätist ja Venemaalt, kuid selle stratigraafiline levik piirdub ainult Kunda lademega. Vikisphaera kesta morfoloogia erineb seni tuntud Ordoviitsiumi mikrofossiilidest, kuid meenutab suuruse ja kesta struktuuri poolest mõnede mereloomade munakapsleid. Töös on püstitatud hüpotees, et kirjeldatud fossiili bioloogiline funktsioon oli olla kestaks tundmatu päritoluga mittefossiliseeruva selgrootu varasele arengustaadiumile. Seni kuni hüpoteesi kinnitamiseks puuduvad kindlad tõendid, võib Vikisphaera arvata akritarhide hulka, mis vastavalt definitsioonile hõlmavad kõiki tundmatu päritoluga orgaanilise kestaga mikrofossiile. 